\title{
Comparative Analysis of the National Accounting Standards of the Czech Republic and Lithuania ${ }^{\#}$
}

\author{
Jonas MACKEVICIUS ${ }^{*}$ - Jiři STROUHAL ${ }^{* *}{ }_{-}$ \\ Svetlana ZVEROVICH ${ }^{* * *}$
}

\section{Introduction}

The globalisation and the expansion of markets as well as the general progress in the technologies available have brought new problems to the compilation of financial reports and to the ascertainment of trading income of supranational corporations and groups in accordance with statutory regulations of countries involved.

Without common accounting standards, there could be 27 different national methods of accounting in addition to the use of IFRS and US GAAP, which are permitted by some EU countries (Whittington, 2005). Brown and Tarca warn that "the future of the IASB is tied to the successful introduction of IFRS in Europe" (Brown - Tarca, 2005). The EU motivates the regulation by referring to the enhanced international comparability and transparency of financial statements and improved access to the international capital markets resulting from IFRS usage (Cuijpers - Buijink, 2005).

\# This paper is recognize as one of the research outputs of the project Development of Financial and Accounting Theory and its Application in Practice from Interdisciplinary Point of View registered at Ministry of Education Czech Republic under MSM 6138439903.

* Prof. Habil. Dr. Jonas Mackevičius - Professor; Department of Accounting, Faculty of Economics, University of Vilnius, Sauletekio 9, LT-2040 Vilnius, Lithuania; $<$ jonas.mackevicius@ef.vu.lt>.

** Jiří Strouhal, Ph.D. - senior lecturer; Department of Financial Accounting and Auditing, Faculty of Finance and Accounting, University of Economics, Prague, W. Churchill Sq. 4, 13067 Prague 3, Czech Republic; <strouhal@vse.cz>.

${ }^{* * *}$ Svetlana Zverovich, Ph.D. MSc. - senior lecturer; Bristol Business School, University of the West of England, Coldharbour Lane, Bristol, BS16 1QY, United Kingdom; $<$ svetlana.zverovich@uwe.ac.uk>. 
In the year 2002, the European Parliament and the Council of the European Union issued Regulation 1606/2002 (European Parliament and of the Council, 2002) ${ }^{1}$ whereby it stipulated certain duties on the part of companies listed on European stock exchanges to compile their consolidated accounting statements in accordance with IFRS. Therefore, beginning from 2005, a large number of listed enterprises, exhibiting significant heterogeneity in size, capital structure, ownership structure and accounting sophistication, started to apply international standards for the first time. The demand for detailed application guidance will increase substantially, as will the demand for uniform financial reporting enforcement throughout the European Union. Schipper states "if the IASB declines to provide detailed implementation guidance for IFRS, I predict that preparers and auditors will turn elsewhere, perhaps to US GAAP or perhaps to jurisdiction-specific European GAAP, for that guidance" (Schipper, 2005).

In addition to the use of IFRS by listed companies, many countries adopt international standards for unlisted companies or model their domestic standards on the basis of international standards. The Australian government had decided to adopt international standards for the statutory accounts of all domestic companies from 2005, and New Zealand has indicated the year 2007. The 2003 survey by Deloitte \& Touche (2003) suggested that more than 90 countries would either require or permit IFRS for listed companies by 2005, and according to the latest Deloitte survey now there are over 100 such countries. This provides an interesting example for those who argue that accounting standards should be left to competition in the marketplace (e.g. Watts - Zimmerman, 1986).

The requirements for group listed enterprises to prepare IFRS reports from 2005 were established in most transitional economies, but it is still unclear to what extent other enterprises will prepare IFRS financial statements. Concerns about the lack of suitably trained accountants and auditors and the lack of efficient markets to ensure reliable fair values for the IFRS financial statements, have already been expressed (Eccher Healy, 2000; Sucher - Alexander, 2002). This may cast doubt on whether

European Parliament and of the Council (2002): Regulation (EC) No 1606/2002 of the European Parliament and of the Council of 19 July 2002 on the application of international accounting standards. Available from <http://eur-lex.europa.eu/LexUr iServ/LexUriServ.do?uri=CELEX:32002R1606:EN:NOT>. 
the financial statements issued under IFRS will be reliable. Indications are that in most of the transitional economies of Eastern and Central Europe, other non-listed enterprises will not have to prepare financial statements according to IFRS (Sucher - Kosmala - Bychkova Jindřichovská, 2005).

From the year 2005, the public listed companies in the Czech Republic should report under the IFRS framework, while the non-listed companies still report under the Czech accounting principles. The Czech Accounting Act was adopted in 1992 and since then has been changed 15 times. Unfortunately, these changes do not comply with the necessity of the harmonisation of the Czech accounting with IFRS. Surprisingly, the definition of the balance sheet items is still missing in Czech GAAP.

Since the restoration of independence in 1990, Lithuania has been rapidly moving to the worldwide market. Its accounting system has changed considerably. In 1997, when the International Accounting Standards (IAS) were translated into Lithuanian by the Accounting Institute of the Republic of Lithuania, an active campaign regarding the preparation of national accounting standards based on the international ones was launched. On 6 November 2001, the Seimas (parliament) of the Republic of Lithuania passed three laws regulating the accounting system: the Republic of Lithuania Accounting $\mathrm{Law}^{2}$, the Law on Financial Statements of Entities ${ }^{3}$ and the Law on Consolidated Financial Statements ${ }^{4}$.

The adoption of IFRS has considerably influenced Lithuanian accounting legislation and practice. The Republic of Lithuania Accounting Law 27 prescribes in Article 3 that entities, whose securities are traded on EU regulated market from 1 January 2005, have to prepare their financial statements in accordance with IFRS.

Lithuania has also prepared the national accounting standards that are called the Lithuanian Business Accounting Standards (LBAS) ${ }^{5}$. The

2 Republic of Lithuania Accounting Law, 6 November 2001, No. IX-574.

3 Republic of Lithuania Law on Financial Statements of Entities, 6 November 2001, No. IX-575.

4 Republic of Lithuanian Law on Consolidated Financial Statements, 6 November 2001, No. IX-575.

5 LBAS, Lithuanian Business Accounting Standards - Lithuanian Institute of Accounting. Available from: $<$ http://www.apskaitosinstitutas $>$. 
LBAS are principle-based standards and their principal provisions are consistent with IFRS. They prescribe main requirements for financial statements and accounting policies for particular accounting areas. Overall, thirty-seven Lithuanian Business Accounting standards have been developed and approved by the Lithuanian Institute of Accounting. According to the Republic of Lithuania Accounting Law (Article 4), since 1 January 2004, limited liability profit-seeking entities are required to comply with the LBAS.

On 7 June 2007, the Parliament of Lithuania passed amendments to the Law on Financial Statements of Entities (No. X-1179), the Accounting Law (No. X-1178) and the Law on Consolidated Accounts of Entities (No. X-1180). According to these amended laws, limited civil liability profit-seeking entities, whose securities are not traded on regulated markets, are allowed to choose to use either the LBAS or IFRS for keeping accounts and preparing financial statements for the financial year starting 1 July 2007 and later.

\section{Czech Regulation}

From the year 2005, IFRS were given as a legal framework for the reporting of listed companies in all E.U. countries (including the Czech Republic and the Republic of Lithuania). The "target user" of the financial statements in the Czech Republic is still the tax authority, not the investor or owner. Moreover, unlike international standards, the Czech accounting regulations lack a glossary of definitions for basic elements of financial statements, which is why we shall use the definitions applied in IFRS standards, namely in the Framework. Reliable measurement is expected from all entries involved.

Concerning the initial recognition under Czech laws, the Accounting Act (Section 24) identifies the following valuation alternatives:

- historical costs, i.e. the cost of acquisition of the assets concerned, including the costs related to the acquisition itself;

- replacement/reproduction cost, i.e. the cost for which the assets would be obtained at the time of the accounting statement;

- production costs, which include all direct costs expended on the manufacturing or other activity and that part of indirect costs, which is related to the manufacturing or other activity involved;

- nominal value, i.e. the face value. 
In the Czech Republic, items are usually measured at historical costs, while donated or gratuitously procured assets are measured by replacement costs, which are the approximate equivalent of the reproduction cost as defined by IFRS. Under certain circumstances, the realizable value and the fair value also may be used as the measurement bases for financial accounting. On the other hand, the Czech regulations virtually ignore measurement methods based on present value (Strouhal Židlická, 2008), which are required for measurement of long-term receivables, long-term payables and financial assets held to maturity (under IFRS).

Under Section 18 of the Accounting Act, the financial statements comprise: balance sheet, profit and loss statement, and notes. At the same time, Section 18 also contains the following unfortunate sentence "the financial statements may also include a cash-flow statement and the statement of changes in equity". This means that under Czech laws, the cash-flow statement is not an obligatory component of the financial statements, not even for the accounting entities, which are liable to statutory audit (Strouhal, 2008). On the other hand, international standards stipulate that the above statements be an integral part of the financial statements. The subsequent text deals mainly with the balance sheet and the P/L Statement.

\subsection{Financial Statements}

The Czech regulations do not require the separate reporting of discontinued operations (Dvořáková, 2008), while IFRS stipulate that discontinued operations be disclosed and presented separately in accordance with IFRS 5. In particular, IFRS 5 stipulates that "the sum of the post-tax profit or loss of the discontinued operation and the post-tax gain or loss recognized on the measurement to fair value less cost to sell or fair value adjustments on the disposal of the assets (or disposal group) should be presented as a single amount on the face of the income statement. Detailed disclosure of revenue, expenses, pre-tax profit or loss, and related income taxes is required either in the notes or on the face of the income statement in a section distinct from continuing operations".

Pursuant to the Fourth Directive of the E.U., accounting entities should compile the profit and loss statement vertically, allowing for the presentation of expenses either according to their nature or function. However, if the profit and loss statement is arranged with respect to the 
function of entries involved, an accounting entity must also include a schedule disclosing the operating costs classified with respect to their nature.

Under IAS 1, an entity should also report the earnings per share ratio (EPS). Unlike US GAAP, international standards do not require that costs be classified as to their function in the profit and loss statement. Instead, they only demand that accounting entities submit an analysis of costs classified as to their nature or function, whichever classification provides more reliable or more relevant information. However, the function-base classification allows for an amount of certain discretion with respect to the assignment of costs to individual functions.

There exist two basic differences between the profit and loss statement compiled in accordance with Czech rules and in compliance with IFRS (Dvořáková, 2008): IFRS have revoked the obligation to report extraordinary expenses and extraordinary revenues - as of 1 January 2005, accounting entities disclose extraordinary expenses and revenues under their other expenses and revenues; the Czech regulations have included the entries for re-allocation of expenses to inventory and fixed assets and change in inventory of finished goods and work in progress among the revenue entries. However, since IFRS do not recognize the above entries as revenues, they have been included among adjustments to operating expenses.

Firms with international stock exchange listings face additional capital market pressures (Meek - Roberts - Gray, 1995) and stock exchange requirements (Cooke, 1992) that may lead them to increase their level of disclosure. Investors demand information about the domestic operating environment and domestic accounting regulations of foreign listed firms (Nobes - Parker, 2002). Many stock exchanges around the world allow foreign registrants to prepare their financial statements according to IFRS or US GAAP. Prior studies show that the level of disclosure (Cooke, 1992; Meek - Roberts - Gray, 1995) and the probability of using non-local GAAP (Ashbaugh, 2001; Dumontier Raffournier, 1998; El-Gazzar - Finn - Jacob, 1999; Leuz, 2003; Leuz Verrecchia, 2000; Murphy, 1999) are positively associated with the number of foreign stock exchange listings of a firm. The impact on financial reporting of cultural differences has been well documented (Nobes - Parker, 2002; Radebaugh - Gray, 2002). There may be more disclosure by UK and US companies that have a culture of disclosure of 
information than by companies that have not traditionally aimed to produce especially transparent financial statements (e.g. companies from transitional economies such as the Czech Republic).

\subsection{Reporting of Balance Sheet Items under Czech Principles}

\subsubsection{Intangible fixed assets}

Intangible fixed assets are intangible assets, which the accounting entity intends to keep for more than one accounting period (the Income Tax Act also specifies that the input price of intangible fixed assets must exceed the sum of CZK 60000 ).

The value of intangible fixed assets is measured by historical cost (acquisition price) for assets purchased, by production costs for internally generated assets and by replacement price for assets obtained gratuitously. Intangible fixed assets are subject to amortization; the amortization period is stipulated by the Income Tax Act. The intangible fixed assets must be accounted for in compliance with the prudence principle as of the balance day, meaning that the accounting entity should disclose either the net book value of the intangible fixed assets, or the lower present market price.

Unlike under the Czech regulations, under IFRS the incorporate expenses as well as research and development (R\&D) should be accounted for under expenses. Under certain circumstances, R\&D may also be capitalized in the balance sheet. Goodwill pursuant to IFRS 3 should be disclosed only in the event that the goodwill was generated by acquisition. Advance payments may be offset against debts from the same title.

\subsubsection{Tangible fixed assets}

Tangible fixed assets include tangible assets, which the accounting entity intends to keep for more than one accounting period (the Income Tax Act also specifies that the input price of the tangible fixed assets must exceed CZK 40 000).

The value of the tangible fixed assets is measured by historical costs (acquisition price) for assets purchased, by production costs for processed 
production and by replacement price for assets obtained gratuitously. Tangible fixed assets are subject to depreciation; the accounting books should show the so-called book depreciation. The tangible fixed assets must be accounted for in compliance with the prudence principle as of the balance day, meaning that the accounting entity should disclose either the net book value or the lower present market price of the tangible fixed assets concerned.

Measurement at fair values is preferred by the international companies in the Czech Republic. We think that there is a good information background for the calculation of the fair value of property, plant and equipment (PPE) or investment property. On the other hand, the Czech Ministry of Finance prefers the prudence principle and also, for the Tax Authorities, it is much easier to find out the historical costs rather than to calculate the fair value.

Financial leases are treated totally differently under Czech GAAP. The "form over substance" principle is fully applied, as it is the leasing company, which reports the leased assets, not the lessee! We think that this is the main problem of Czech GAAP nowadays and has great consequences for financial decisions. Also, it should be stated here the unwillingness of the Czech Ministry of Finance to solve the problem with financial leases as under IFRS, where the traditional principle "substance over form" is used.

\subsubsection{Inventories}

Inventories are current assets consumed by an entity during one year or within one operating cycle for generating revenues. Usually, we distinguish between inventory purchased and processed production.

At the time of acquisition, the value of inventories is measured by the historical costs (acquisition price for purchased inventories), replacement price (for inventories obtained gratuitously) and production costs (for processed production).

For the measurement of the value of inventory decrement, the same cost formula should be used for all inventories with similar characteristics as to their nature and use to the enterprise. For groups of inventories that have different characteristics, different cost formulas may be justified, including FIFO, the weighted average cost formula, the fixed inventory 
price with independent disclosure of variations or the actual acquisition price.

Accounting entities are entitled to choose from the continuous inventory system (method A) and the periodic inventory system (method B) for inventory records. In the continuous inventory system, accounting entities record inventories via account groups Materials, Processed Production and Goods and allocate inventory decrement to costs (Raw Materials, Resale of Raw Materials, Consumables and Purchased Finished Goods) or to income adjustments (group Change in Inventory (Stocks)). In the periodic inventory system, accounting entities record the purchased inventories in the relevant costs accounts and during the accounting period do not even use balance-sheet entries such as Inventory of Materials and Consumables or Inventory Purchased for Resale - In Storage. Instead, as of the balance day, the accounting entity transfers the initial status of the balance-sheet entries into costs and based on the stocktaking results transfers from the costs the final status of purchased inventories into the balance sheet.

Inventories must be accounted for in compliance with the prudence principle as of the balance day, meaning that the accounting entity must record the inventories with their book value or with their lower present market value.

\subsubsection{Receivables, payables and credits}

The short-term and long-term receivables constitute a part of current assets, while short-term and long-term payables are included among liabilities.

Both receivables and payables should be measured by their nominal value, unless obtained in exchange for consideration, in which case they should be measured by their acquisition price. The impossibility to measure the long-term receivables and long-term payables at their present value (what is also possible e.g. in Slovakia) is quite surprising. Accounting entities must convert receivables and payables in foreign currencies as of the moment of their measurement to Czech crowns in accordance with the current exchange rate of the Czech National Bank or a fixed exchange rate. As of the balance date, the accounting entities must also convert the sum of pending receivables and payables to Czech crowns in accordance with the current exchange rate of the Czech 
National Bank. Foreign currency exchange losses and gains should be recognized in the income statement.

The deferred tax assets and liabilities arise from the differences between the accounting and taxation concepts of selected accounting entries. The accounting for the deferred taxes is based on the assumption that the accounting entity will apply the deferred tax in a later period than the due tax. The recognition and the accounting for the deferred tax are mandatory for entities, which form the consolidation units (i.e. enterprises within a group) and the accounting entities, which are obliged to compile the final accounts in their full extent. Other accounting entities may account for the deferred tax at their own discretion. The accounting for the deferred tax does not affect the tax liability. At the same time, it affects the sum of disposable profit, i.e. profit intended for allocation. The calculation of the deferred tax should be based on the balance-sheet approach. The deferred tax should be recognized for all temporary differences arising from the different accounting and tax views of entries included among assets and liabilities. It is also necessary to account for differences between the tax and tax residual price of the deductible tangible and intangible fixed assets as well as for other differences such as the reserves created beyond the scope of statutory duty, recognition of adjustments to inventories or receivables etc.

Credits and financial assistance should be measured at their nominal value.

\subsubsection{Cash}

Short-term financial assets are included among the current assets of an enterprise. We distinguish between cash in hand, cash at bank and shortterm securities. Cash items are measured at their nominal value, while short-term securities are measured by the historical costs (acquisition price). Short-term securities are measured at fair values, however it should be stated that it is quite difficult to measure the fair values of shares because of not very transparent stock exchange in the Czech Republic (Prague Stock Exchange). 


\subsubsection{Provisions}

The Accounting Act stipulates that only the genuine profits should be accounted for in the balance sheet, and that the accounting entity should take into consideration all predictable risks and possible losses affecting its assets and liabilities and known to the accounting entity at the time of balance sheet compilation. Also, it should include all devaluations regardless of the fact whether the accounting entity showed profit or loss in the accounting period. The accounting entity is entitled to use provisions, adjustment entries and write-offs for that purpose. Provisions are aimed to cover future expenses or liabilities, whose purpose is known and which are expected to occur, but whose timing or amount is uncertain. However, provisions may not be used to adjust the value of assets.

Provisions may be used only for the purpose for which they have been originally recognized. Logically, a provision may only be used to the maximum amount in which it was created; and a provision may not have a debit balance. The balance of reserves at the end of the accounting period should be transferred to the subsequent period. Accounting entities are obliged to review provisions entered in the books at the end of the accounting period, and assess their tenability and amount. If it is discovered that the reason for which the provision has been created has lapsed, the provision should be dissolved in its full extent. If it is discovered that the provision is for a different sum than it is due, it should be adjusted. In the balance sheet, provisions should be accounted for under liabilities.

The Accounting Act defines the following types of reserves: provisions for risks and losses, provisions for income tax, provisions for pensions and similar obligations, provision for restructuring, technical provisions or other provisions pursuant to special legal regulations (statutory provisions).

The Provision Act stipulates three types of provisions for enterprises: provision for repairs of tangible assets, provision for cultivation of crops, other provisions (for the removal of mud from a pond, for the redevelopment of plots affected by mining, for the settlement of mine damage or provisions stipulated by special laws as costs required to achieve, ensure or maintain revenues). 


\section{Financial Reporting in Lithuania: LBAS (Lithuanian Business Accounting Standards)}

The Republic of Lithuania Law on Financial Statements of Entities (RL LFSE) sets up the following financial statements: Balance Sheet; Profit (Loss) Statement; Cash Flow Statement; Statement of Changes in Equity; and Explanatory Notes. The RL LFSE also establishes the main requirements for the compilation of financial statements.

According to the RL LFSE, there are the following requirements for the compilation of financial statements:

- At the beginning of financial reports, the following particulars must be given:

- Name, code and address of the registered office of an entity;

- Date of financial statements;

- The level of precision used in the presentation of figures (indicators) in financial statements (it shall be specified whether the indicators are expressed in litas, thousands of litas, etc).

The financial statements of an entity must preserve headings of the items given in sample reports, numbering and ordering thereof.

Entities shall draw up annual financial statements at the end of their financial year.

Entities shall draw up interim financial statements where necessary or on a periodic basis specified by other legal acts. Newly registered entities shall draw up a balance sheet of the commencement of economic activities indicating the assets, equity and liabilities of an entity at the commencement of activities.

Financial statements shall be drawn up using the monetary unit of the Republic of Lithuania (the litas).

Financial statements shall be drawn up in the Lithuanian language and, where necessary, in a foreign language.

All economic operations and economic events of an entity must be accounted prior to the drawing up of financial statements. 
Accounting data shall be based on the data of the stocktaking of assets and liabilities. The procedure for stocktaking shall be set forth by the Government or an institution authorised by it.

The financial year of an entity shall last 12 months. Entities shall select the financial year by taking account of the nature of their activities. The financial year may be changed due to a change of the nature of activities of an entity (not more than once per five years) or due to consolidation of financial statements (in this case, a subsidiary undertaking shall be allowed to change the financial year and to agree it with the financial year of a parent undertaking) 29.

The Framework for the preparation and presentation of financial statements in Lithuania is LBAS 1 'Financial Statements'. It is very similar to the IASB Framework for the preparation and presentation of financial statements. It prescribes the basic concepts by which financial statements are prepared, and provides definitions, short descriptions of the financial statements, evaluation methods of the elements of statements and references to other standards, where accounting requirements for the above financial statements are determined. According to LBAS 1, "the purpose of financial statements shall be to satisfy the needs of information users with regard to receiving correct information about the entity's financial condition, performance and cash flows". However, it does not define main users of financial reporting.

General accounting principles are consistent with the international ones and include the following concepts and accounting principles: entity's concept; going concern; periodicity; consistency; monetary measure; accrual; comparison; prudence; neutrality; substance over form (LBAS 1, Article 28).

According to LBAS 1 (Article 16), the elements of financial statements can be measured by using a number of different measurement bases:

- historical cost;

- fair value;

- net realizable value;

- net realization value;

- present value;

- value in use; 
- amortised cost.

In financial statements the majority of elements are carried by entities at historical costs, unless the LBAS establish otherwise. The entities are free to select the measurement bases of the elements of financial statements on their own discretion if such methods are not established by the LBAS.

More detailed provisions for each statement are written in separate standards such as LBAS 2 'Balance Sheet', LBAS 3 'Income Statement', LBAS 4 'Statement of Changes in Equity', LBAS 5 'Cash Flow Statement' and LBAS 6 'Explanatory Notes'. Note that LBAS 6 defines Explanatory Notes as a separate statement, whereas according to IAS 1 'Presentation of Financial Statements', Explanatory Notes only explain and analyse items in Balance Sheet, Income Statement, Statement of Changes on Equity, and Cash Flow Statement. According to the both standards LBAS 6 and IAS 1, Explanatory Notes comprise three parts: general part, accounting policy and notes. However, the requirements for Explanatory Notes in LBAS 6 are more detailed than in IAS 1. In contrast to IAS 1, LBAS 6 prescribes what information should be disclosed in each part of Explanatory Notes.

LBAS 2, LBAS 3, LBAS 4, LBAS 5 and LBAS 6 include requirements for the preparation and presentation of annual financial statements, composition and general requirements for their scope. For instance, LBAS 2 'Balance Sheet' prescribes how the information about the company's assets, equity and liabilities has to be presented, classified and disclosed on the balance sheet. Furthermore, it gives detailed definitions of a balance sheet, an asset, non-current assets, reserves, a revaluation reserve etc. In addition, LBAS 2 prescribes different forms of a balance sheet for different types of entities and also provides examples of the following balance sheet forms:

- complete form of the balance sheet (86 items);

- short form of the balance sheet (21 items);

- agriculture company's complete form of the balance sheet (94 items);

- agriculture company's short form of the balance sheet (25 items);

- state and municipality entity form of the balance sheet (78 items). 
The standard also gives the possibility to present additional line items in the balance sheet if necessary. The important difference between IAS 1 'Presentation of Financial Statements' and LBAS 2 'Balance Sheet' is that the former does not prescribe the format of a balance sheet and the order in which balance sheet items need to be presented. According to LBAS 2 'Balance Sheet', it is compulsory that assets and liabilities are grouped into non-current assets, current assets, non-current liabilities and current liabilities. Whereas according to IAS 1 , there is also a possibility to apply exception when the presentation of items in a balance sheet is based on liquidity providing information that is reliable and more relevant.

IAS 1 prescribes requirements only for a complete set of financial statements, while the LBAS define not only a complete set of financial statements, but also a short one (abridged annual financial statements) that does not include Cash Flow Statement. The short set of financial statements comes from the RL LFSE. According to this Law (Article 24), the short form of financial statements can be presented by entities that do not exceed the limit of two of the following criteria on the balance sheet day within two years:

- balance sheet total: 5 million litas;

- net income: 7 million litas;

- average number of employees during the financial year: 10 people.

Please note that the litas was pegged to the Euro on 2 February 2002 at a fixed exchange rate 34528 litas per 1 Euro2. Additionally, entities compiling a short set of financial reports may also prepare short Explanatory Notes.

There is also a difference between IAS 1 'Presentation of Financial Statements' and LBAS 3 'Income Statement'. LBAS 3 gives only one structure of Income Statement, whereas according to IAS 1, entities may present an analysis of expenses using classification based on either the nature of expenses or their function within the entity, whichever provides information that is reliable and more relevant and encourages entities to present information on the face of Income Statement. Moreover, IAS 1 allows presenting some information in notes. There are also other differences between IAS 1 and the LBAS, for instance, according to LBAS 4 'Statement of Changes in Equity', all entities are required to 
provide Statement of Changes in Equity, whereas IAS 1 'Presentation of Financial Statements' allows presenting Statement of Changes in Equity or Statement of Recognised Income and Expense.

\subsection{Basic Differences Between LBAS and IFRS}

\subsubsection{Intangible Fixed Assets}

According to LBAS 13 'Intangible Assets', an intangible asset is an "identifiable non-monetary asset without physical substance disposed by the enterprise expecting to obtain direct and indirect economic benefits from the use of such asset". Intangible assets should be recognised if they satisfy the definition of intangible assets and the following three recognition criteria:

- The enterprise can reasonably expect to obtain future economic benefits from the assets;

- The historical (production) cost of the assets can be reliably measured and distinguished from the value of other assets;

- The enterprise can dispose such assets, control them or limit the others' right to use such assets. Intangible assets are carried at the acquisition (production) cost (LBAS).

Overall, LBAS 13 is consistent with IAS 38 'Intangible Assets' but the difference between them is that intangible assets cannot be revaluated under LBAS 13.

\subsubsection{Tangible Fixed Assets (Non-Current Tangible Assets)}

LBAS 12 identifies non-current tangible assets as "tangible assets which rendering economic benefits to the enterprise for a period exceeding one year and the acquisition (production) costs of which is not lower than the minimum value of non-current tangible assets estimated by the enterprise".

Although main provisions of the standard are very similar to those of IAS 16 'Property, Plant and Equipment' and IAS 40 'Investment Property', there are some differences. So, LBAS 12 defines an additional criterion for recognition of non-current tangible assets. That is the acquisition (production) cost of the asset should be not lower than the 
minimum cost of non-current tangible asset estimated by an enterprise per each group of assets. The next difference is that interest is not included in the asset acquisition (production) cost. It is recorded under expenses of respective periods. In addition, unused non-current tangible assets including preserved assets are exempt from calculation of depreciation. Also, there are some differences in the principles of accounting of noncurrent tangible assets acquired in exchange for other assets, e.g. no gain or loss is recognised on the transaction when "the value of assets is not specified in the exchange agreement, and assets of the same or similar designation, nature and value being exchanged are used in the same line of business" (LBAS).

\subsubsection{Inventories}

The main difference between LBAS 9 'Inventories' and IAS 2 'Inventories' is that under LBAS 9 it is possible to apply not only the FIFO and weighted average cost methods but also LIFO in some cases. For example, "when the items of inventory which were purchased or produced last are sold first, and consequently the items remaining in inventory at the end of the period are those first purchased or produced" (LBAS). The other essential differences do not exist between these standards.

\subsubsection{Income Tax}

Provisions of LBAS 24 'Income Tax' are consistent with provisions of IAS 12 'Income Statement'. LBAS 24 allows enterprises not to apply LBAS 24 if they prepare abridged annual financial statements or if enterprises use complete forms of balance sheet and income statement but their deferred tax amounts are immaterial.

\subsubsection{Derivatives, Financial Assets and Financial Liabilities}

There are no essential differences between the procedure of recognition of and accounting for derivatives set forth under LBAS 26 'Derivatives' and IAS 32 'Financial Instruments: Disclosure and Presentation' and IAS 39 'Financial Instruments: Recognition and Measurement'. 
Also, the principles of accounting for financial assets and financial liabilities established under LBAS 18 'Financial Assets and Financial Liabilities' and IAS 39 are very similar. However, for the purpose of recognition and measurement, LBAS 18 classifies financial assets into the following four groups:

- intended-for-sale;

- held-to-maturity;

- originated long-term loans and receivables (including current portion of non-current loans and receivables); and

- originated short-term loans and receivables (LBAS).

Whereas, according to IAS 39, financial assets are classified in one of the following categories:

- financial assets at fair value through profit or loss (this category has two subcategories: designated and held for trading);

- available-for-sale financial assets;

- loans and receivables;

- held-to-maturity investments.

Thus, LBAS 18 does not include the group Available-for-sale financial assets and all financial assets that are not attributed to the categories of Held-to-maturity; Originated long-term loans and receivables; or Originated short-term loans and receivables, are treated as Intended-for-sale and changes in their value are recognised as profit or loss in Income Statement.

\subsubsection{Provisions, Changes in Foreign Exchange Rates, and Impairment of Assets}

There are no essential differences between LBAS 19 'Provision, Contingent Liabilities and Contingent Assets, and Events Occurring after the Balance Sheet Date' and the corresponding IAS 10 'Events After the Balance Sheet Date' and IAS 37 'Provisions, Contingent Liabilities and Contingent Assets'. Also, the provisions of LBAS 22 'Changes in Foreign Exchange Rates' correspond to the provisions of IAS 21 'The Effects of Changes in Foreign Exchange Rates'; and essential differences between LBAS 23 'Impairment of Assets' and IAS 36 'Impairment of Assets' do not exist. 


\section{Conclusion}

In the Czech Republic, the most significant problem of financial statements and items shown is the complete inconsistency of the measurement bases and the application of the historical (acquisition) cost, fair value and present value (Buus - Strouhal - Brabenec, 2007). At present, the principle of measurement based on the historical cost fades out as it is being gradually replaced by the IFRS trend of reporting fair values, which are, however, difficult to measure in less transparent markets. At the same time, the reporting based on fair value includes a hidden danger of future volatility of such values and the consequent impact of the changes on financial statements.

Jindřichovská and McLeay state that "the Czech market is similar to more developed markets, at least in one respect: there is statistically significant evidence of different market effects of profits and losses, in that profits are more persistent than losses. However, contrary to the findings in more developed markets, there is no statistically significant evidence of earnings conservatism in the Czech market" (Jindřichovská - McLeay, 2005). These results are most probably due to the continuing influence of restrictive tax regulations that mitigate any tendency towards conservatism, as well as the transitional nature of the economy. Thus, if changes in market prices signal good news and bad news about future risky outcomes, there is no evidence of asymmetry in the Czech market in accounting for such risks.

In the Republic of Lithuania, the LBAS are the national accounting standards that are aimed at regulating the issues of accounting, which are topical for Lithuania. Therefore, the national standards, while being based on IFRS, are not word-for-word copy thereof. One of the most important differences is that the LBAS are more detailed than IFRS, written in a simpler language and adapted for small and medium-sized entities. Also, the LBAS provide the sample reporting forms of financial statements for different types of entities so that there are different forms of financial statements for agriculture companies, state and municipality entities and other limited profit-seeking entities. The scope of the annual financial reporting depends on the type and size of an entity. Micro entities, which fulfil the requirements set by the Law on Financial Statements of Entities of the Republic of Lithuania, can present the short set of financial statements. The responsibility for entity's financial statements shall rest upon the head of the entity. 


\section{References}

[1] Ashbaugh, H. (2001): Non-U.S. Firms' Accounting Standards Choices. Journal of Accounting and Public Policy, 2001, vol. 20, no. 2, pp. 129-153.

[2] Brown, P. - Tarca, A. (2005): A Commentary on Issues Relating to the Enforcement of International Financial Reporting Standards in the EU. European Accounting Review, 2005, vol. 14, no. 1, pp. 181212.

[3] Buus, T. - Strouhal, J. - Brabenec, T. (2007): How to Valuate Your Company - Comparison of the Approaches for Listed and Non-listed Companies. Prague, Oeconomica, 2007.

[4] Cooke, T. E. (1992): The Impact of Size, Stock Market Listing and Industry Type on Disclosure in the Annual Reports of Japanese Listed Corporations. Accounting and Business Research, 1992, vol. 22, no. 87, pp. 229-237.

[5] Cuijpers, R. - Buijink, W. (2005): Voluntary Adoption of Non-local GAAP in the European Union: A Study of Determinants and Consequences. European Accounting Review, 2005, vol. 14, no. 3, pp. 487-524.

[6] Deloitte \& Touche (2003): Use of IFRS for Reporting by Domestic Listed Companies by Country. [on-line], New York, Deloitte \& Touche, c2003, [cited 20 $0^{\text {th }}$ March, 2008],

$<$ http://www.iasplus.com/country/useias.htm>.

[7] Dumontier, P. - Raffournier, B. (1998): Why Firms comply Voluntary with IAS: An Empirical Analysis with Swiss Data. Journal of International Financial Management and Accounting, 1998, vol. 9, no. 3, pp. 216-245.

[8] Dvořáková, D. (2008): Financial Accounting and Reporting under IFRSs. Brno, Computer Press, 2008.

[9] Eccher, E. - Healy, P. (2000): The Role of International Accounting Standards in Transitional Economies: A Study of the People's Republic of China. [on-line], Social Science Research Network, c2000, [cited 20 $0^{\text {th }}$ March, 2008],

$<$ http://papers.ssrn.com/sol3/papers.cfm?abstract_id=233598>.

[10] El-Gazzar, S. M. - Finn, P. M. - Jacob, R. (1999): An Empirical Investigation of Multinational Firms' Compliance with International 
Accounting Standards. International Journal of Accounting, 1999, vol. 34 , no. 2 , pp. 239-248.

[11] Jindřichovská, I. - McLeay, S. (2005): Accounting for Good News and Accounting for Bad News: Some Empirical Evidence from the Czech Republic. European Accounting Review, 2005, vol. 14, no. 3, pp. 635-655.

[12] Leuz, C. (2003): IAS versus U.S. GAAP: Information Asymmetrybased Evidence from Germany's New Market. Journal of Accounting Research, 2003, vol. 41, no. 3, pp. 445-472.

[13] Leuz, C. - Verrecchia, R. E. (2000): The Economic Consequences of Increased Disclosure. Journal of Accounting Research, 2000, vol. 38, supplement, pp. 91-124.

[14] Meek, G. K. - Roberts, C. B. - Gray, S. J. (1995): Factors Influencing Voluntary Annual Report Disclosures by U.S., U.K. and Continental European Multinational Corporations. Journal of International Business Studies, 1995, vol. 26, no. 3, pp. 555-572.

[15] Murphy, A. B. (1999): Firm Characteristics of Swiss Companies That Utilize International Accounting Standards. International Journal of Accounting, 1999, vol. 35, no. 1, pp. 121-131.

[16] Nobes, C. - Parker, R. (2002): Comparative International Accounting. Englewood Cliffs, Prentice-Hall, 2002.

[17] Radebaugh, L. - Gray, S. (2002): International Accounting and Multinational Enterprises. New York, Wiley, 2002.

[18] Schipper, K. (2005): The Introduction of International Accounting Standards in Europe: Implications for International Convergence. European Accounting Review, 2005, vol. 14, no. 1, pp. 101-126.

[19] Strouhal, J. (2008): ACONTIS - Professional Information for Accounting Practices (CD). Prague, ASPI Wolters Kluver, 2008.

[20] Strouhal, J. - Židlická, R. (2008): Financial Reporting 2008. Brno, Computer Press, 2008.

[21] Sucher, P. - Alexander, D. (2002): IAS: Issues of Country, Sector and Audit Firm Compliance in Emerging Economies. London, Centre for Business Performance of the Institute of Chartered Accountants in England and Wales, 2002. 
[22] Sucher, P. - Kosmala, K. - Bychkova, S. - Jindřichovská, I. (2005): Transitional Economies and Changing Notions of Accounting and Accountability. European Accounting Review, 2005, vol. 14, no. 3, pp. 571-577.

[23] Watts, R. - Zimmerman, J. (1986): Positive Accounting Theory. Englewood Cliffs, Prentice-Hall, 1986.

[24] Whittington, G. (2005): The Adoption of International Accounting Standards in the European Union. European Accounting Review, 2005, vol. 14, no. 1, pp. 127-153. 


\title{
Comparative Analysis of the National Accounting Standards of the Czech Republic and Lithuania
}

Jonas MACKEVICIUS - Jiř́ STROUHAL - Svetlana ZVEROVICH

\begin{abstract}
The European Union (EU) Regulation 1606/2002 requires all listed companies of the member states to prepare consolidated financial statements based on the International Financial Reporting Standards (IFRS) for accounting periods beginning on or after 1 January 2005. The adoption of IFRS is supported in many countries inside and outside the European Union because it may improve the quality and comparability of financial reporting. In addition to the use of IFRS by listed companies and in some countries also by unlisted companies, many countries have developed their own national accounting standards based on the international ones. Although the national standards are based on IFRS, they are not identical. The Czech Republic and Lithuania are transitional economies that joined the European Union in May 2004. The purpose of the paper is to compare national accounting standards of the Czech Republic and Lithuania with IFRS, look at approaches of these countries to aspects of financial reporting, and analyze differences and similarities in the approaches.
\end{abstract}

Key words: Financial Reporting; European Union; International Financial Reporting Standards; Czech GAAP; Lithuanian Business Accounting Standards (LBAS).

JEL classification: M41. 